\title{
GAMBARAN DOSIS TERAPI PADA PASIEN PROGRAM TERAPI RUMATAN METADON DI RSUD GUNUNG JATI KOTA CIREBON
}

\section{DESCRIPTION OF THERAPY DOSAGES FOR THE PATIENT OF METHADONE TREATMENT PROGRAM IN RSUD GUNUNG JATI CIREBON}

\author{
Rinto Susilo $^{\mathbf{1}}$, Aida Maftuhah ${ }^{\mathbf{1}}$ \\ 1. Akademi Farmasi Muhammadiyah Cirebon \\ Jl. Cideng Indah no. 3 Cirebon \\ Email : rintosusilo88@yahoo.com \\ Email : aidamaftuhah@gmail.co.id
}

\begin{abstract}
ABSTRAK
Badan Narkotika Negara (BNN) mencatat jumlah pengguna NAPZA di Indonesia terus meningkat. Masalah gangguan penggunaan NAPZA suntik menjadi salah satu media penularan HIV di Indonesia sejak tahun 1999. Penelitian dilakukan untuk mengetahui dosis rumatan pada pasien PTRM di RSUD Gunung Jati Kota Cirebon, penelitian dilakukan dengan cara desain observasional, data yang diambil adalah data rekapitulasi penggunaan dosis metadon yang diambil dari tahun 2009-2015. Hasil penelitian di dapatkan bahwa karakteristik pasien dari jenis kelamin laki-laki 58 orang $(98,3 \%)$, perempuan 1 orang $(1,7 \%)$, usia $20-29$ tahun 17 orang $(28,8 \%)$, usia $30-39$ tahun 37 orang $(62,7 \%)$ dan usia 40-49 tahun 5 orang $(8,5 \%)$, pendidikan SMA 41 orang $(69,5 \%)$, SMP 3 orang $(5,1 \%)$, perguruan tinggi 15 orang $(25,4 \%)$, pekerjaan Wiraswasta 35 orang $(61 \%)$, tidak bekerja 16 orang (27\%), karyawan 4 orang $(6,8 \%)$, PNS 2 orang $(3,4 \%)$, ibu rumah tangga 1 orang $(1,7 \%)$, status menikah 48 orang $(81,4 \%)$, belum menikah 11 orang $(18,6 \%)$, dan dosis terapi rumatan yang diberikan yaitu antara $35 \mathrm{mg}-295 \mathrm{mg}$ metadon perhari. Dosis rumatan yang sesuai dengan dosis anjuran yaitu $60 \mathrm{mg}-120 \mathrm{mg}$ sebanyak 44 orang $(75,6 \%)$ dan dosis yang melebihi $120 \mathrm{mg}$ sebanyak 15 orang $(25,4 \%)$.
\end{abstract}

Kata kunci: Metadon, Dosis terapi rumatan, RSUD Gunung Jati.

\begin{abstract}
State Narcotics Agency (BNN) record the number of drug users in Indonesia continues to increase. Problems injecting drug use disorders become one of transmission media of HIV in Indonesia since 1999. The study is held to know the maintenance dosage of PTRM patients in RSUD Gunung Jati Cirebon. The study is conducted by using the observational design. The data are data recapitulation of methadone dosage taken from 2009-2015. The study results are got that patient characteristics for the male gender 58 people (98.3\%), female $1(1.7 \%), 17$ people aged $20-29$ years $(28.8 \%)$, age $30-39$ in $37(62.7 \%)$ and $40-49$ years age $5(8.5 \%)$, high school education $41(69.5 \%)$, SMP $3(5.1 \%)$, college/university 15 people ( $25.4 \%)$, Entrepreneur 35 people $(61 \%)$, unemployees 16 people $(27 \%)$, employees $4(6.8 \%)$, government employees 2 (3.4\%), housewives 1 ( $1.7 \%)$, married status of 48 people $(81.4 \%)$, unmarried $11(18.6 \%)$, within the maintenance therapy dosage which is given is between 35mg-295mg of methadone per day. The maintenance dosage which fits to the recommended dosage is $60 \mathrm{mg}-120 \mathrm{mg}$ many as 44 people $(75.6 \%)$ and dosage which exceeds $120 \mathrm{mg}$ as many as 15 people(25.4\%).
\end{abstract}

Keywords: Methadone maintenance therapy dose, Gunung Jati Hospital. 


\section{PENDAHULUAN}

Masalah besar yang menjadi persoalan global dan meningkat secara cepat lonjakannya di Asia, termasuk Indonesia adalah penyalahgunaan narkotika, alkohol, psikotripika dan zat adiktif lainnya (NAPZA) dan penularan HIV/AIDS. Badan Narkotika Nasional (BNN) mencatan jumlah pengguna NAPZA di Indonesia terus meningkat, walaupun secara pasti sulit diketahui jumlahnya. Berdasarkan hasil estimasi yang dilakukan oleh BNN pada tahun 2004 diperkirakan ada 3,2 juta orang (1,5\% populasi), pada tahun 2008 (1,9\%), tahun 2011 (2,2\%), dan di tahun 2014 diperkirakan jumlahnya 3,8 juta sampai 4,1 juta orang $(2,1 \%$ sampai $2,25 \%)$ di Indonesia yang mempunyai riwayat menggunakan narkotika (BNN, 2014).

Masalah gangguan penggunaan NAPZA suntik menjadi salah satu media penularan utama HIV di Indonesia sejak tahun 1999. Tahun 2006-2011 jumlah kasus HIV yang disumbangkan oleh populasi pengguna NAPZA suntik adalah sebanyak 4.758 kasus ( $34 \%$ ) (Kemenkes), sementara data laporan triwulan Direktorat Pengendalian Penyakit dan Penyehatan Lingkungan (Ditjen PP dan PL) sampai juni 2010 menunjukkan bahwa propinsi dengan prevalensi pengguna NAPZA suntik tertinggi adalah DKI Jakarta, Jawa Barat, Jawa Timur ,Sulawesi Selatan Dan Bali (Anonim, 2013).

Pecandu opiat umumnya menggunakan heroin dan sebagian besar dari mereka menggunakan heroin dengan cara suntik yang tidak aman, baik dari segi peralatannya yang cenderung dipakai berulang dan bergantian, maupun lokasi penyuntikan pada tubuh yang umumnya tidak dibersihkan terlebih dahulu. Akibatnya, mereka sangat mudah mendapat infeksi seperti tetanus, sepsis maupun virus lain yang menular melalui darah seperti Hepatitis (B,C,D) dan HIV. Guna mengurangi dampak buruk penggunaan opiat dengan cara suntik, diperlukan intervensi pengurangan dampak buruk (harm reduction). Salah satu kegiatannya adalah program terapi rumatan dengan memberikan Metadon dalam sediaan cair, yang dikenal dengan nama Program Terapi Rumatan Metadona (PTRM). PTRM ini adalah sebagai terapi substitusi yaitu terapi yang bertujuan untuk mengganti penggunaan zat seperti heroin atau morfin dengan Metadon. Dosis yang digunakan pada fase rumatan atau tahap pemeliharaan ini bervariasi untuk masing-masing individu. Fase rumatan tersebut dapat berlangsung lama sampai klien benar-benar merasa stabil, untuk kemudian ke fase reduksi atau tahap penghentian yang dilakukan secara bertahap. Program Terapi Rumatan Metadon (PTRM) yang ada di Kota Cirebon, tepatnya di RSUD Gunung Jati Kota Cirebon ternyata sudah ada sejak tahun 2009, tetapi masih banyak petugas kesehatan maupun masyarakat luas yang tidak mengerti tentang program ini. Penelitian ini bertujuan Untuk mengetahui karakteristik pasien Program Terapi Rumatan Metadon (PTRM) di RSUD Gunung Jati Cirebon dan mengetahui dosis rumatan metadon yang diberikan pada pasien Program Terapi Rumatan Metadon (PTRM) di RSUD Gunung Jati Kota Cirebon.

\section{METODE PENELITIAN}

\section{Bahan}

Subjek penelitian adalah semua data rekam medik pasien di PTRM RSUD Gunung Jati Cirebon yang mengikuti Program Terapi Rumatan Metadon lebih dari 6 bulan dan memenuhi kriteria inklusi dan kriteria eksklusi. Kriteria inklusi antara lain: Pasien yang menjalani terapi dari tahun 2010 sampai dengan Desember 2015 yang telah menjalani terapi lebih dari 6 (enam) bulan sedangkan kriteria eksklusi antara lain: Pasien yang keluar (droup out) dan pasien yang dirujuk atau pindah ke layanan PTRM lain.

Data primer penelitian ini berupa demografi pasien dan dosis penggunaan metadon pasien PTRM RSUD Gunung Jati Cirebon. Data sekunder penelitian adalah dosis rumatan yang dianjurkan Permenkes Republik Indonesia Nomor 57 tahun 2013 tentang Pedoman Penyelenggaraan Program Terapi Rumatan Metadon yaitu 60-120 mg perhari.

Metode

Penelitian ini merupakan penelitian observasional. Pengambilan data dilakukan secara retrospektif berupa data rekapitulasi penggunaan dosis Metadon di PTRM RSUD Gunung Jati Cirebon. 


\section{Jalannya Penelitian}

Teknik pengumpulan data dalam penelitian ini adalah melalui pengamatan langsung/ observasi dari rekam medik pasien dengan menggunakan Lembar Pengumpul Data (LPD) yang berisi data nama pasien beserta identitas dan dosis rumatan pasien.

\section{Analisis Data}

Analisis data menggunakan teknik analisis univariat (analisis deskriptif). Dalam analisis ini umumnya hanya menghasilkan distribusi frekuensi dan persentase jumlah demografi pasien serta dosis rumatan yang diberikan kesesuaiannya dengan dosis rumatan yang dianjurkan Permenkes Republik Indonesia Nomor 57 tahun 2013 tentang Pedoman Penyelenggaraan Program Terapi Rumatan Metadon yaitu 60-120 mg perhari.

\section{HASIL DAN PEMBAHASAN}

\section{A. Karakteristik Pasien}

Penelitian dilakukan terhadap pasien terapi rumatan metadon yang menjalani terapi di Depo PTRM Rumah Sakit Umum Daerah Gunung Jati Kota Cirebon. Secara keseluruhan total pasien yang menjalani terapi sebesar 92 pasien dari semua populasi. Pasien yang aktif sampai dengan desember 2015 adalah 19 pasien (20,65\%), sedangkan sisanya sebesar 73 pasien $(79,35 \%)$ mengalami drop out, pindah terapi dan meninggal dunia. Dalam penelitian ini, hanya meneliti pasien yang telah menjalani terapi lebih dari 6 bulan dan memenuhi kriteria inklusi dan kriteria eklusi yaitu sebesar 59 pasien $(64,1 \%)$. Data karakteristik pasien pada penelitian ini dapat dilihat di tabel 1.

Tabel 1. Karakteristik Pasien PTRM RSUD Gunung Jati Cirebon.

\begin{tabular}{lll}
\hline Karakteristik pasien & Jumlah & Persen \\
\hline Jenis kelamin & & \\
Laki-laki & 58 & $98,3 \%$ \\
Perempuan & 1 & $1,7 \%$ \\
\hline Usia & & \\
20-29 & 17 & $28,8 \%$ \\
30-39 & 37 & $62,7 \%$ \\
40-49 & 5 & $8,5 \%$ \\
\hline Pendidikan & & \\
SMP & 3 & $5,1 \%$ \\
SMA & 41 & $69,5 \%$ \\
Perguruan Tinggi & 15 & $25,4 \%$ \\
\hline Pekerjaan & & \\
Karyawan & 4 & $6,8 \%$ \\
Wiraswasta & 35 & $61 \%$ \\
Tidak bekerja & 16 & $27 \%$ \\
PNS & 1 & $1,7 \%$ \\
IRT (ibu rumah tangga) & 2 & $3.4 \%$ \\
\hline Status Pernikahan & & \\
Menikah & & \\
Belum menikah & 48 & $81,4 \%$ \\
& 11 & $18,6 \%$ \\
\hline Penyakit penyerta HIV & & \\
HIV positif & 25 & $42,4 \%$ \\
Non HIV positif & 34 & $57,6 \%$ \\
\hline
\end{tabular}


Sampel penelitian terdiri atas 58 laki-laki $(98,3 \%)$ dan 1 perempuan $(1,7 \%)$ dengan kisaran usia antara 20-50 tahun, terdiri atas usia 20-29 tahun sebesar 17 orang $(28,8 \%)$, usia 3039 tahun sebesar 37 orang $(62,7 \%)$ dan sisanya usia 40-49 tahun sebesar 5 orang $(8,5 \%)$, hal ini juga hampir sama dengan data laporan mei 2005 dari PTRM RSKO dan klinik PTRM RS Sanglah Denpasar dimana pasien laki-laki lebih banyak, RSKO sebanyak 90\% dan RS Sanglah sebanyak 95\% (Anonim, 2006). Hal ini sesuai dengan data narkoba di tingkat nasional berdasarkan penelitian "Studi Biaya Sosial dan Ekonomi Penyalahgunaan dan Peredaran Gelap Narkoba" yang dilakukan oleh BNN dan Puslitkes UI pada tahun 2004 bahwa pecandu Laki-laki prosentasenya lebih besar jika dibandingkan dengan Perempuan. Hal ini juga sesuai dengan data penelitian yang dilakukan oleh BNN dan Puslitkes UI pada tahun 2014, bahwa pecandu laki-laki lebih besar (91\%) jika dibandingkan dengan Perempuan (BNN, 2014). Sedangkan usia terbanyak di PTRM Cirebon antara 30-39 tahun. Hal ini sesuai dengan ketentuan yang direkomendasikan dari Pedoman Nasional Program Terapi Rumatan Metadon oleh Depkes, yaitu Klien yang mengikuti PTRM berusia 18 tahun atau lebih, dan apabila klien berusia kurang dari 18 tahun maka harus mendapatkan second opinion dari profesional medis lain. Dari penelitian yang dilakukan BNN di tahun 2005 didapat data kasus narkoba di Indonesia tertinggi pada usia lebih dari 29 tahun, sedangkan data dari RSKO didapat bahwa penyalahgunaan narkoba tertinggi pada usia 20-29 tahun yaitu sebesar 73\% pasien RSKO dan di RS Sanglah usia terbanyak diatas 25 tahun(Anonim, 2006).

Tingkat pendidikan paling banyak SMA atau sederajat yaitu sebesar 41 orang $(69,5 \%)$, SMP 3 orang $(5,1 \%)$, perguruan tinggi 15 orang $(25,4 \%)$, di PTRM RSKO 65\% berpendidikan SMA , data dari BNN menyebutkan $70 \%$ tamat SMA untuk wilayah Bali, Jatim, DIY, NTB, dan 15\% tamat akademi / PT untuk wilayah Jabar, NTB, Sumatra utara (BNN, 2014. Dari segi pekerjaan yaitu Wiraswasta 35 orang (61\%), tidak bekerja 16 orang (27\%), karyawan 4 orang $(6,8 \%)$, PNS 2 orang $(3,4 \%)$, ibu rumah tangga 1 orang $(1,7 \%)$, di PTRM RSKO tingkat sosial ekonomi menengah keatas yang lebih banyak. Status menikah 48 orang $(81,4 \%)$, belum menikah 11 orang $(18,6 \%)$, data dari BNN justru lebih banyak yang belum menikah 63,8\% (BNN, 2014). Terdapat 25 orang dengan HIV positif $(42,4 \%)$, tergolong cukup tinggi. Menurut data dari Depkes (2005) kasus HIV/AIDS di Indonesia karena faktor penularan dari Pengguna Narkoba Suntik (Penasun) sebesar 50\% (Anonim, 2006).

\section{B. Gambaran Dosis Metadon.}

Dosis awal yang diterima pasien berkisar antara 20-30 mg. Dosis tersebut sudah sesuai pedoman terapi rumatan metadon. Pemberian dosis awal memperhatikan prinsip keamanan mengingat mortalitas tertinggi pada terapi rumatan metadon terjadi pada hari-hari pertama terapi. Kematian bisa terjadi bila menggunakan dosis awal yang melebihi $40 \mathrm{mg}$. Pasien harus diobservasi 45 menit setelah pemberian dosis awal untuk memantau tanda-tanda toksisitas atau gejala putus obat. Jika terdapat intoksikasi atau gejala putus obat berat maka dosis akan dimodifikasi sesuai dengan keadaan. Kemudian dosis rumatan yang dianjurkan rata-rata 60-120 mg per hari. Penambahan dosis selalu harus didahului dengan evaluasi ulang pada pasien. Hasil tes urin yang positif terhadap heroin menjadi pertimbangan untuk meningkatkan dosis metadona. Disamping itu pemakaian obat-obatan yang dapat berinteraksi dengan metadon juga dapat menjadi pertimbangan dokter untuk meningkatkan dosis metadon. Dosis rumatan rata-rata sampel antara 35-295 mg per hari. Rincian dapat dilihat di tabel 2. 
Tabel 2. Dosis Rumatan di PTRM RSUD Gunung Jati Cirebon kesesuaian dengan dosis anjuran Permenkes Republik Indonesia Nomor 57 tahun 2013 tentang Pedoman Penyelenggaraan Program Terapi Rumatan Metadon

\begin{tabular}{lcc}
\hline \multicolumn{1}{c}{ Karakteristik dosis } & Jumlah & Persen \\
\hline Dosis rumatan : & 44 & $74,6 \%$ \\
$<120 \mathrm{mg}$ (sesuai anjuran Depkes) & 15 & $25,4 \%$ \\
$>$ 120mg (tidak sesuai anjuran Depkes) & & \\
\hline Dosis rumatan >120mg & 8 & \\
HIV positif & 7 & \\
Lain-lain & & \\
\hline
\end{tabular}

Dosis rumatan pada pasien PTRM Cirebon yang sesuai anjuran yang direkomendasikan dari Pedoman Nasional Program Terapi Rumatan Metadon oleh Depkes yaitu antara 60-120 mg perhari, terdapat $74,6 \%$ atau sebanyak 44 pasien, dan yang tidak sesuai anjuran terdapat $25,4 \%$ atau sebanyak 15 pasien. Dan dari 15 pasien diantaranya HIV positif. Hal ini dimungkinkan adanya interaksi metadon dan obat ARV (nevirapine dan efavirenz), obat ARV ini dapat menurunkan kadar metadon, dikarenakan obat ARV tersebut menginduksi metabolisme metadon di hati, sehingga metabolisme metadon menjadi lebih cepat dan berpengaruh pada peningkatan dosis metadonnya, walaupun peningkatan dosis metadon tergantung dari keluhan dan gejala klinis. Di samping itu juga pemberian dosis rumatan yang tinggi bisa terjadi karena pasien juga menderita infeksi paru, hal ini di sebabkan adanya interaksi obat metadon dengan rifampicin dimana rifampicin dapat merangsang enzim hati yang terlibat dalam metabolisme metadon sehingga dapat menurunkan kadar metadon.Selain itu juga pada pasien dengan gangguan penggunaan NAPZA Tipe Multipel yaitu pasien seringkali juga menggunakan obat-obat lain (golongan benzodiazepin/ anti depresan) dan alkohol dengan dosis yang mengganggu kesehatan.

\section{KESIMPULAN}

1. Karakteristik pasien Program Terapi Rumatan Metadon di klinik PTRM RSUD Gunung Jati Kota Cirebon adalah :

a. Jenis kelamin, terdiri atas : 58 laki-laki $(98,3 \%)$ dan 1 perempuan $(1,7 \%)$

b. Usia antara 20-50 tahun, terdiri atas : usia 20-29 tahun sebesar 17 orang $(28,8 \%)$, usia 30-39 tahun sebesar 37 orang $(62,7 \%)$ dan sisanya usia 40-49 tahun sebesar 5 orang $(8,5 \%)$

c. Tingkat pendidikan, terdiri atas : SMA 41 orang $(69,5 \%)$, SMP 3 orang $(5,1 \%)$ dan Perguruan Tinggi 15 orang $(25,4 \%)$

d. Status pekerjaan, terdiri atas : 35 orang wiraswasta (61\%), 4 orang karyawan $(6,8 \%), 16$ orang tidak bekerja $(27 \%), 2$ orang PNS $(3,4 \%)$ dan 1 orang ibu rumah tangga $(1,7 \%)$

e. Status pernikahan, terdiri atas :48 orang menikah $(81,4 \%)$ dan 11 orang belum menikah $(18,6 \%)$

f. Dengan penyakit penyerta HIV, terdiri atas : 25 orang dengan HIV positif $(42,4 \%)$ dan 34 orang non HIV $(57,6 \%)$

2. Dosis rumatan pada pasien Program Terapi Rumatan Metadon di klinik PTRM RSUD Gunung Jati Kota Cirebon adalah : antara $35 \mathrm{mg}-295 \mathrm{mg}$ per hari. Dan dosis rumatan $<120 \mathrm{mg}$ sebanyak 44 orang $(74,6 \%)$ dan dosis rumatan $>120 \mathrm{mg}$ sebanyak 15 orang $(25,4 \%)$ dan 8 orang diantaranya terinfeksi virus HIV . 


\section{DAFTAR PUSTAKA}

Anonim, 1979, Farmakope Indonesia, edisi III, Departemen Kesehatan RI, Jakarta.

Anonim, 2006, Keputusan Menteri Kesehatan Republik Indonesia Nomor 494/Menkes/SK/VII/2006 tentang Penetapan Rumah Sakit dan Satelit Uji Coba Pelayanan Terapi Rumatan Metadon serta Pedoman Program Terapi Rumatan Metadon

Anonim, 2008, Keputusan Menteri Kesehatan Republik Indonesia Nomor 350/Menkes/SK/IV/2008 tentang Penetapan Rumah Sakit Pengampu dan Satelit Program Terapi Rumatan Metadon serta Pedoman Program Terapi Rumatan Metadon

Anonim, 2009, Undang-Undang Republik Indonesia Nomor 44 tahun 2009 tentang Rumah Sakit.

Anonim, 2011, Keputusan Menteri Kesehatan Republik Indonesia Nomor 421/Menkes/SK/III/2011 tentang Standart Pelayanan Terapi Dan Rehabilitasi Gangguan Penggunaan NAPZA.

Anonim, 2013, Peraturan Menteri Kesehatan Republik Indonesia Nomor 57 tahun 2013 tentang Pedoman Penyelenggaraan Program Terapi Rumatan Metadon.

Anonim, 2014, Peraturan Menteri Kesehatan Republik Indonesia Nomor 56 tahun 2014 tentang Klasifikasi dan Perizinan Rumah Sakit.

BNN \& Puslitkes UI, 2004, Studi Biaya Ekonomi \& Sosial Penyalahgunaan Narkotika di Indonesia tahun 2004, Depok : Puslitkes UI.

BNN, 2014, Laporan Akhir Survei Nasional Perkembangan Penyalahgunaan Narkotika Anggaran 2014: Jakarta.

Hawari. D, 2000, Penyalahgunaan Narkotika dan Zat Adiktif, Fakultas Kedokteran Umum Universitas Indonesia : Jakarta.

Lumbantobing, 2007, Serba Serbi Narkotika,Fakultas Kedokteran Universitas Indonesia : Jakarta.

Maramis. W.F, 2005,Catatan Ilmu Kedokteran Jiwa, Airlangga University Press: Surabaya. 